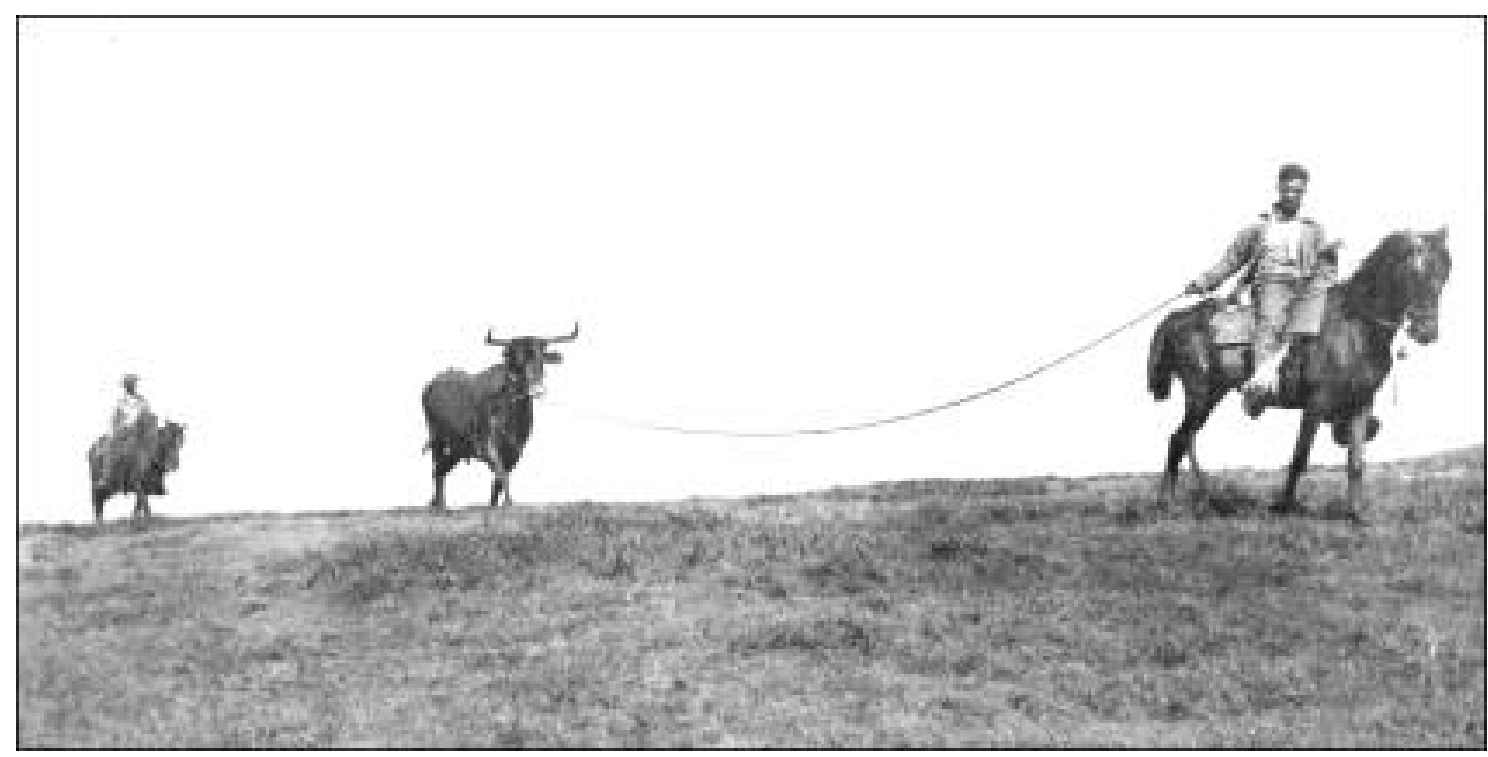

Fig. 1. Wild cattle were moved with some care and long leads. Courtesy of the Bishop Museum, Henriques Collection.

\title{
The Millennial Hawaiian Paniolo
}

\author{
Paul F. Starrs
}

A cross the American West, for 150 years, the number of real working ranch hands has in truth been anything but large. When a million miners thronged through $1850 \mathrm{~s}$ California, fewer than ten thousand or so cowhands (many of them Native American, Hispanic, or black) were working from Missouri to the Pacific. But the western ranch hand has assumed a symbolic prominence far out of proportion to actual numbers. Ranching was a force for change, part of a striving economy, and something novel upon the land (Starrs 1998). Into this neatly fits the Hawaiian cowboy, or paniolo, the wild Hawaiian country, and, of course, pua'a pipi, the beef provender they provided. And yet, more folks are today familiar with the ukulele, the lei, or the lilting notes of Hawaiian song than are knowledgeable about the origins and significance of ranching done the Hawaiian way.

Everyone conveniently recollects that Pilgrims were the earliest Europeans to settle the North American continent. That "fact" is about as predictably wrong as it is ethnocentric; in Santa Fe, New Mexico, was a thriving Hispanic community and a finely formed full-on city a resolute thirty years before the English Pilgrims even thought to set sail for Plymouth. Inconvenient facts are swiftly forgotten. Among the most elusive details, even for aficionados of western Americana, is how early among ranch hands the Hawaiian paniolo really ranks. Paniolos were close descendents of the California vaqueros; the word for Spaniard, Español, became in its Hawaiian rendering "paniolo," just as "vaquero," in the parlance of Nevada and California, became "buckaroo" (Starrs and Huntsinger 1998).

\section{Origins}

The American West, even in the mid1800 s, was part of a great and reaching empire that could be said to stretch to the mid-Pacific Ocean (Meinig 1993). In 1803 , the horse arrived shipboard to Hawai' $i$, brought in an attempt to permit Hawaiians to travel their rugged backcountry swiftly and safely. Cattle came to the Islands still earlier, in 1793, as a gift to Kamehameha I, the king who had, despite some odds, mostly unified the Hawaiian Islands under a single sovereign. Cattle were immediately called pua'a pipi-literally, "beef pigs." The name made perfect sense; the pig was the domesticated animal that had traveled with Polynesians for weeks on great ocean-going canoes that originally populated the islands. The King took receipt with pleasure, if also with a measure of nervous anticipation, as contemporary traveler Thomas Manby would write in 1793 (Manby 1959):

The cattle greatly delighted [the King], though it took some time to quiet his fears lest they should bite him. He called them large hogs, and after much persuasion we prevailed on him to go close up to them; at that instant one of the poor animals, turning its head around quickly, so alarmed his majesty that he made a speedy retreat and ran over half his retinue. His fright was not of long duration and ceased on seeing some of his attendants take them by the horns. ...The four cows were in tolerable condition and had got very tame by being on board. The concourse of people to see them landed was immense; we were a good deal diverted at seeing the terror the whole village was thrown into by 
one of the cows galloping along the beach and kicking up her heels. (24-25)

Cattle numbers increased at close to the biological maximum. Two of the first cows were pregnant; three bulls were brought the following year, in 1794 (Brennan 1974, 30). King Kamehameha I had immediately imposed a kapu, the Hawaiian word for taboo, on killing the livestock for a decade after arrival; the penalty for even injuring an animal was death (Manby 1959; Strazar 1987; Bryan and Brakha 2000). Captain George Vancouver did report in his journal having asked for such strict protection: "the king alone...could appropriate a certain number of the [bull cattle] to his table; but [we asked] that in doing so the women should not be precluded partaking of them, as the intention of [the cattle] being brought to the island was for the general use and benefit of every inhabitant of both sexes, as soon as their general numbers should be sufficiently increased to allow for a general distribution amongst the people" (Vancouver, quoted in Brennan 1974).

In terms of timing, 1793 was four decades before The Alamo, a generous eighty years before the great cattle drives along the Chisolm and other trails, and fully 140-plus years before the Taylor Grazing Act. By no small stretch of the clock, the Hawaiian cowboy, or paniolo, predates the Texas and Great Plains range rider; only the California buckaroo has a like age. Cattle eventually became a significant trade product of the $19^{\text {th }}$ century Islands. It is no accident that, in the era before statehood when Hawai' $i$ had its own currency, the fifty dollar bill was decorated with a ranching scene (Bryan and Brakha 2000).

Through these early years, the Hawaiian cattle were of undistinguished breed: long horned and fast-moving criollos of formidable temper and Alta California origin, they roamed the oftendense forests and dined on the native rangelands with impunity (Figure 1). "By 1813, twenty years after being introduced, the animals had so multiplied that they had become a nuisance, devouring and trampling the natives' crops of potatoes, ravishing their taro patches, and in short, raising havoc with whatever was planted" (Brennan 1974, 45). Five to ten years old when caught, some animals could top 1000 pounds-perhaps trifling by modern animal science standards, but how many of us have come face to face with a wild cow or bull five feet tall at the shoulder and with horns that spanned four feet?

\section{Paniolo Arrivals}

Nemesis of these rampaging animals would be the paniolo. Like much else in Hawai ' $i$, the Hawaiian cowboy's origins were on the mainland, imported from Spanish and Mexican Alta California (Lyons 1892). Before long, though, more and more paniolos were homegrown on the Hawaiian islands. At first in the employ of the King, by the 1850 s paniolos would begin moving to ranches being established throughout the islands as part of the great mahele, a disamortization of property removing it as an exclusive domain of Hawaiian royalty to become instead land a larger public might obtain and own (Chinen 1958, Juvik and Juvik 1998, Bryan and Brakha 2000). With land ready to be made into ranches, cattle to be had at low cost, skilled workers available, and a ravenous market for whatever beef and hides the islands could supply, the cattle business boomed (Wellmon 1973).

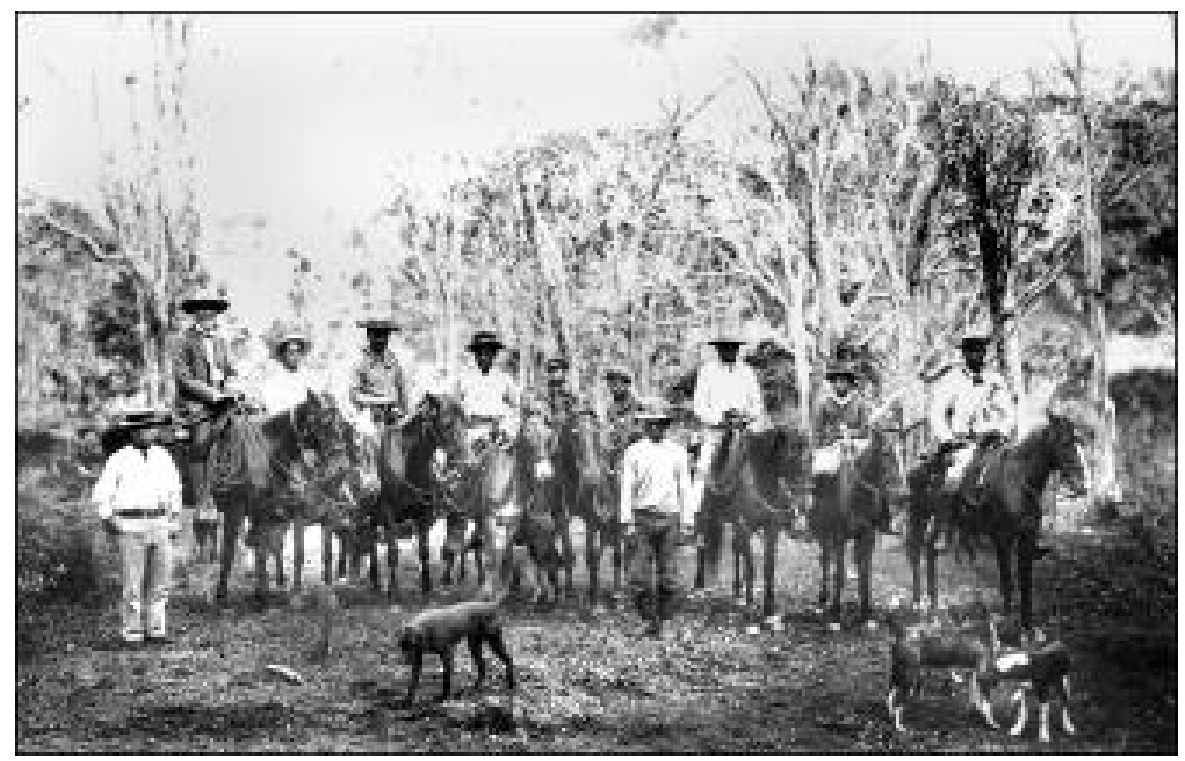

Fig. 2. Photograph of Kaholuamanu Riders and Francis Gay, in full paniolo regalia, Kaua i, circa 1900. Courtesy of The Bishop Museum, Honolulu, Gartley Collection.
As a crowd, paniolos were rawhide tough, descendents in technique and heritage of the Spanish vaqueros (Figure 2). Francis Olmsted, a visitor in the 1840 s, set the scene:

Immediately back of these, a group of fine-looking men, in a peculiar costume, were leaning against the counter of the store. Some of them were Spaniards from California, and they were all attired in the poncho, an oblong blanket of various brilliant colors, having a hole in the middle through which the head is thrust. The pantaloons are open from the knee downwards on the outside, with a row of dashing gilt buttons along the outside seam. A pair of boots armed with prodigiously long spurs complete their costume. They were "bullock hunters," employed in capturing the wild bullocks that roam the mountains, and had just returned from an expedition of eight or ten days, in which they had been very successful. (1959, 78-79)

Not only was a distinctive look established, so too was an actual functioning technique. It was a straight distillation from California tradition, and none of it was for the faint of heart: 
Great numbers of wild bullocks are caught in the mountains every year by the hunters. The lasso, the principal instrument in their capture, is made of braided thongs, upon one end of which is a ring forming a slip noose, which is thrown with astonishing precision around any part of the animal. Even while at full gallop in pursuit, the hunter grasps his lasso, and giving it two or three twirls around his head with the right hand throws it unerringly and entangles his victim by the horns or limbs. And now, be wary for thy life, bold hunter; for the savage animal is maddened with terror. See, he turns upon his pursuer, with eyeballs glaring with fire and his frame quivering with rage. But the well-trained horse springs to one side, and braces himself, while the unwieldy animal plunges forward, but is suddenly brought up by the lasso, and falls with a heavy momentum on the ground. (Olmsted 1959, 79)

Other paniolo techniques ranged across a gamut of usual vaquero practice. Cattle would be roped and tied by the horns to a tree, and at the end of a good day, one paniolo might be responsible for up to a dozen wild cattle bound to trees at the edge of a clearing. They would be left there overnight, until heads and horns grew sore. The caught wild cattle would be yoked to tame animals who were herded to the clearing. The two animals, one domesticated and sedate, the other savage but sore, would slowly work their way back to distant corrals.

Or large pits would be exhumed along cow trails, where animals would fall in and be recovered and roped out later by paniolos checking their trap lines. The cattle had their share of victories; travelers were warned to stay away from the mountains because of the ongoing risk to life and limb. Estimates of livestock numbers were impressive: perhaps 25,000 wild cattle on the Big Island of Hawai' $i$ in 1846, and 10,000 tame cattle; at least 2,000 hides were exported annually in the 40 years from 1845 to 1884 . Through all this, paniolos perished with some regularity; it was a dangerous business. A hand would be issued an entire string of horses, sometimes up to twenty, and be expected to produce from that bevy of broomtails a manageable string of saddle horses (Cowan-Smith and Stone 1988). Stockbreaking techniques, often including belaboring with a two-by-four or its equivalent, were nothing to impress the Horse Whisperer. As Parker Ranch historian Joseph Brennan would write, "It was a hard, raw life, but the men were working in a paradise of a land with unbelievably good weather most of the time. The biggest virtue was that they were doing the thing they most wanted to do." (Brennan 1974, 57)

\section{Wild Cattle Reach the Ranch}

The Parker Ranch was the first large ranch outfit formed on the Hawaiian islands, established in 1847. John Palmer Parker, who had jumped ship on the Big Island with a friend, Jack Purdy, spent several years learning to work the wild cattle, garnered a commission as a bullock hunter for Kamehameha, and ultimately married a granddaughter of Kamehameha I, Chiefess Kepikani. With land grants from the king, Parker eventually had upwards of 300,000 acres. Though somewhat reduced today, the remaining acreage makes the Parker Ranch the largest privately held ranch in the United States (in cattle numbers it is third largest after the King Ranch of Texas and the Deseret Ranch in Florida), and in acreage it ranks among the world's largest (Fullard-Leo 1993, Bryan and Brakha 2000) (Figure 3). Although the ownership has grown more complex, and some of the acreage is now in high-tone subdivisions, the Parker Ranch, elegantly wrapped around 13,796-foot Mauna Kea, remains one of several dozen surviving large ranches in the islands. Its 150 years of operation makes it a Hawai'i institution.

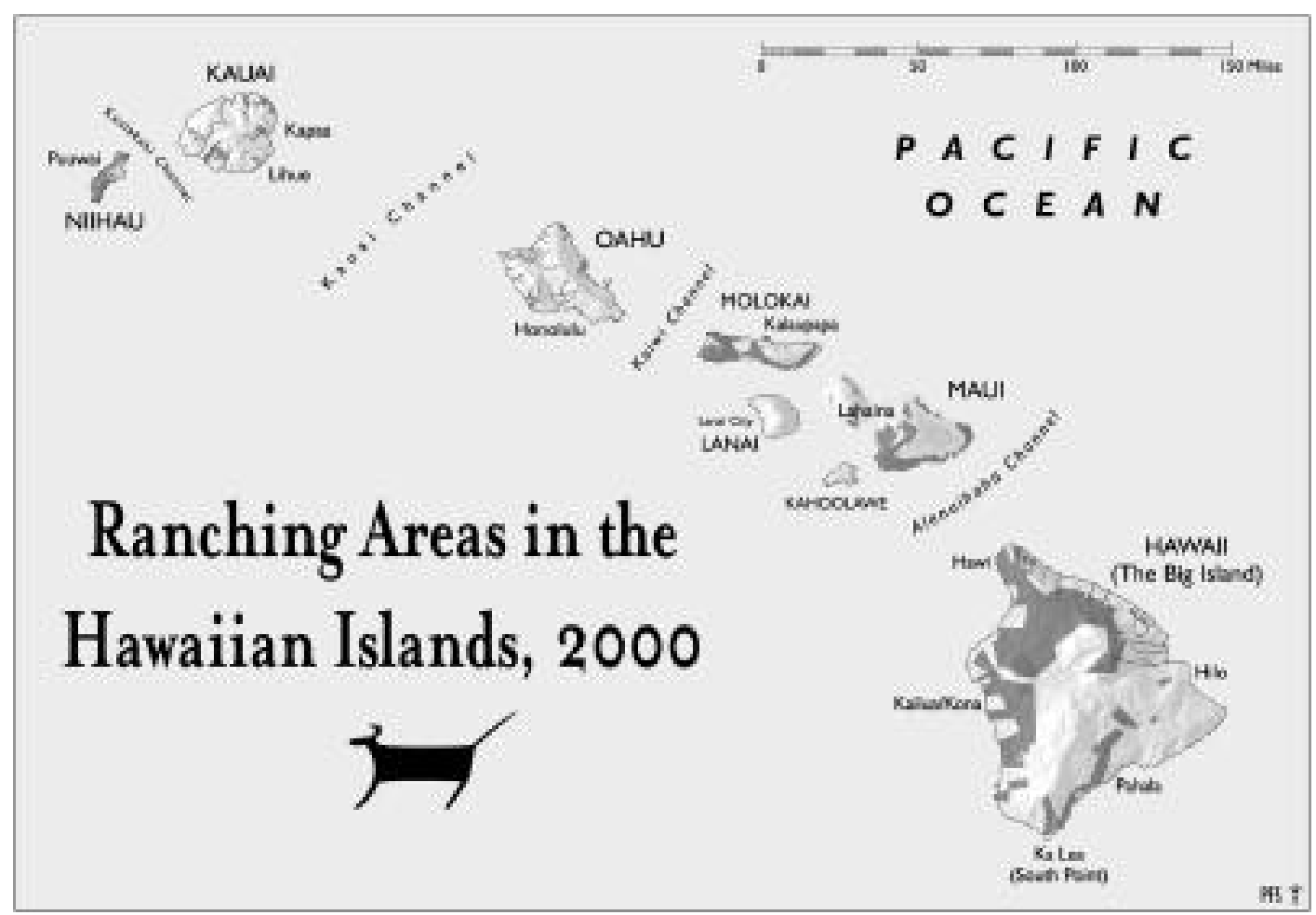

Fig. 3. Ranch Lands of the Hawaiian Islands, 2000; based upon data in Juvik and Juvik (1998) and Martin (1987); map by Paul F. Starrs. 


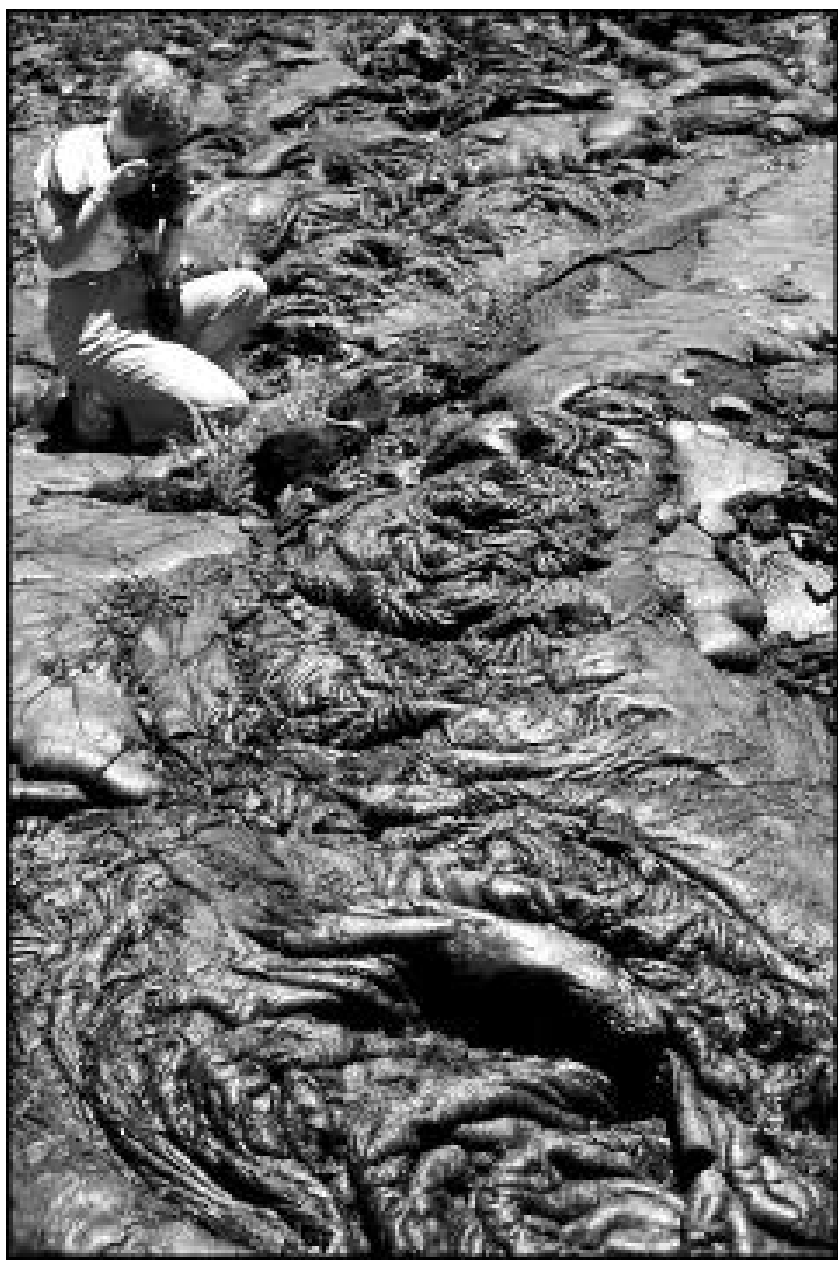

Fig. 4. Lava fields of Hawai'i may today seem like something of interest only to tourists and volcanologists, but in the heyday of Big Island ranching, not so long removed, crossing this kind of territory was necessary. (Photo by Paul F. Starrs).

Hawaiian cattle ranches tend to be on the uplands, where breezes and the moderating effect of rising elevation make for a less stringent environment. That does, in many cases, leave the coastal zones for modern beach-going tourists, and visitors to ranches outside the Parker Ranch operations in Waimea are not common. Other big outfits include the Kahua Ranch, the Kealakekua Ranch, and the Pu'uwa'awa'a Ranch, all of the Big Island, and the Moloka'i Ranch on the "Friendly Island" of Molokai'i (Cooke 1949, Bryan and Brakha 2000). On Maui are a handful of large ranches including 33,000 private acres (and 6000 head) of the Haleakala Ranch, and the late Ikua Purdy's famous 'Ulupalakua Ranch. There remain sizable operations on Kaua'i and the native
Hawaiian operation on Ni'ihau (Martin 1987, Fullard-Leo 1993, Bryan and Brakha 2000). In 1900, ranches made up 1.4 million acres of land, with over 100,000 head of cattle grazing the acreage. These days, more and more of the cattle born on the islands are actually shipped by boat to the mainland for fattening, since it makes no sense, given islandgrown feed prices, to try and bulk up the animals locally.

\section{Change}

Since the mid- $19^{\text {th }}$ century, ranches in Hawai' $i$ have, predictably, changed somewhat. The days when Parker Ranch hands rose at $2 \mathrm{am}$, so they could move their herds of cattle through lava fields before the sun rose and transformed the ropy pahoehoe lava into a literal inferno are mostly gone (Figure 4). There are still several hundred "authentic" paniolos on the islands, and no less than buckaroos in Nevada or cowboys in west Texas, they bemoan changes that have inevitably taken place.

Strikingly, however, many aspects of paniolo life, arrived at through decades of experience, remain. Hands will sport hats decorated with feather, shell, or dryflower leis. Perhaps this is not so common on workdays, but traditions hold for more festive events. Women were not often working cowhands, except on a few of the smaller family or Hawaiian Homeland properties, though they developed a distinctive apparel that is still worn on occasion, the voluminous pa'us that were a feature of pre-statehood celebrations (Rose and Keawe 1987).

The Hawaiian range has also been al- tered. Some of the alterations are so monumental that they are barely perceptible; the entire landscape looks different. For example, on the Big Island of Hawai' $i$, many of the streams that used to drain to the west were diverted, at the upper reaches, and actually now flow eastward, through elaborate tunnels, under the divide and back to the eastern watersheds, where the captured water is used for irrigating sugar cane and other crops. The northwest of Hawai ' $i$ is, therefore, much drier now than it would have been 100 years ago, and an entirely new vegetation is in place. Improved livestock breeds came in as early as the 1860 s, and cattle in the islands have a multifarious shading and lineage of little resemblance to the hearty criollos of 200 years ago. And the more progressive ranches have brought in improved pasture grasses, often of African subtropical origin, which are immediately evident to specialists, but have nothing to do with the precontact vegetation. High-intensity, short-duration grazing systems are in use at some ranches; veterinary care has improved, and the wild cattle of yore are no longer a factor.

And yet, for all that, the paniolo remains a force in the Hawaiian Islands. They are the subject of a number of books, recordings (Trimillos 1987), essays (Martin 1987, Rose and Keawe 1987), and exhibitions at major museums. The Hawaiian cowboy still works the range, but like cowhands in the American West, is not so often evident...unless you know where to look.

\section{The Death of Nature, or, At Least, of the Naturalist...}

In 2001, more than a thousand range managers from across North America will arrive on the island of Hawai 'i. They will scuff their way through convention-hall astroturf, relish the kona (dry) west coast of the Big Island, or head out on field excursions to Hawaiian rangelands, and roam through the rangelands and subdivisions on aa or pahoehoe lava. There, Society for Range Management members will seek to ply their trade. They might choose, though, to watch their step. The old days of the paniolos are not so far gone; as William 
Faulker is alleged to have said, "the past isn't dead, it isn't even past." Those botanizing and socializing might recall what happened to the late Professor Douglas in the 1830s (Olmsted 1959, 80):

The bullocks of the mountains were till within a year or two very numerous and savage, so that traveling among the mountains was attended with great danger. For their capture, a mode frequently resorted to by the hunters was to dig deep pits and cover them with underbrush and dirt. A very melancholy casualty occurred three or four years since among the mountains. A gentleman named Douglas, of distinguished attainments as a naturalist, was engaged in a scientific exploration of the volcano. He had nearly accomplished the objects of his excursion when he met with an awful fate. As he was leaving an encampment where he had spent the night, he was particularly cautioned respecting three bullock pits that lay along the path he was expecting to take. He mistook the directions given him, it is presumed, for the first that was seen of him afterwards was when he was discovered by some natives, in one of the bullock pits under the feet of a savage bull, who was trampling him and goring him in the most terrific manner! The bull was very soon killed, and the mangled body of the unfortunate naturalist drawn out, but life had long since become extinct.

Watch your step!

\section{References Cited}

Brennan, J. 1974. The Parker Ranch of Hawaii: the saga of a ranch and a dynasty. Harper \& Row, New York.

Bryan, M., and M. Brakha. 2000. Aloha dude! Condé Nast Traveler. (January) 108-115, 201-203.

Chinen, J. J. 1958. The great mahele: Hawai'i's land division of 1848 . University of Hawaii, Honolulu.

Cooke, G. P. 1949. Moolelo o Molokai: a ranch story of Molokai. Honolulu StarBulletin, Honolulu, Hawaii.

Cowan-Smith, V., and B. D. Stone. 1988. Aloha cowboy. University of Hawaii Press, Honolulu.

Friedman, K. 1991. God's own cowboys. The New York Times. Monday, 18 March: A11 (National Edition), Col. 5.

Fullard-Leo, B. 1993. Paniolo country. Aloha Magazine. January-February, 40-45, 59.

Juvik, S. P., and J. O. Juvik [eds]. 1998. Atlas of Hawai'i, Chief Cartographer Thomas R. Paradise, Third Revised ed., University of Hawai 'i Press, Honolulu.

Lyons, C. J. 1892. Traces of Spanish influence in the Hawaiian Islands. Hawaiian Historical Society Papers of 1904, Hawaiian Historical Society Paper No. 2: 25-27.

Manby, T. 1959 [1929]. With Vancouver at Kealakekua Bay, reprinted in: A Hawaiian reader. A. G. Day, and C. Stroven (selectors \& eds), 20-36. Mutual Publishing Paperback Series, Tales of the Pacific. Honolulu, Hawaii.

Martin, L. J. 1987. [editor and proj. dir.]. Na Paniolo o Hawai' $i$ : A traveling exhibition celebrating paniolo folk arts and the history of ranching in Hawai 'i. Honolulu Academy of Arts State Foundation on Culture and the Arts. Honolulu Academy of Arts, Honolulu, Hawai 'i.

Meinig, D. W. 1993. The shaping of America: a geographical perspective on 500 years of history, Vol. 2: continental America, 1800-1867. Yale University Press, New Haven, Conn.
Olmsted, F. A. 1959 [1841]. Bullock hunters of the Kohala Range, reprinted in: A Hawaiian reader. A. G. Day, and C. Stroven (selectors \& eds), 77-81. Mutual Publishing Paperback Series, Tales of the Pacific, Honolulu, Hawaii.

Rose, R. G. and D. K. Keawe. 1987. Looking good-Part II , In: L. J. Martin [ed. and proj. dir.]. Na Paniolo o Hawai 'i: A traveling exhibition celebrating paniolo folk arts and the history of ranching in Hawai'i, pp. 73-82. Honolulu Academy of Arts State Foundation on Culture and the Arts. Honolulu Academy of Arts, Honolulu, Hawai'i.

Starrs, P. F. 1998. Let the cowboy ride: cat tle ranching in the American west. Johns Hopkins University Press, Baltimore, Md.

Starrs, P. F. and L Huntsinger. 1998. The cowboy \& buckaroo in American ranch hand styles, Rangelands, 20 (5): 36-40.

Strazar, M. D. 1987. Ranching in Hawai' $i$, In: L. J. Martin [ed. and proj. dir.]. Na Paniolo o Hawai' $\mathrm{i}$ : A traveling exhibition celebrating paniolo folk arts and the history of ranching in Hawai'i, pp. 17-24. Honolulu Academy of Arts State Foundation on Culture and the Arts. Honolulu Academy of Arts, Honolulu, Hawai'i.

Trimillos, R. O. 1987. Na Mele o Paniolo: the songs of Hawaiian cowboys. The State Foundation on Culture and the Arts, Honolulu, Hawaii.

Wellmon, B. 1973. Frontier traders and pioneer cattlemen: an Hawaiian perspective. Hawaiian Journal of History 7: 48-54.

Author is Associate Professor, Department of Geography, University of Nevada, Reno, NV 89557-0048 